Universidad de Lima

Facultad de Derecho

Carrera de Derecho

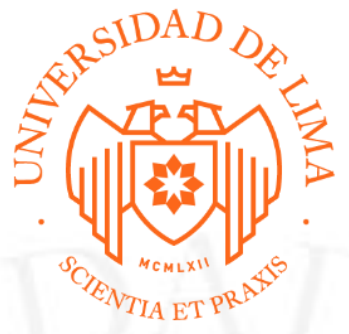

\title{
ARBITRAJE: "ANULACIÓN DE LAUDO ARBITRAL" Y ADMINISTRATIVO: "PROCEDIMIENTO ADMINISTRATIVO SANCIONADOR"
}

Trabajo de suficiencia profesional para optar el Título Profesional de Abogado

Grace Jackeline Sandoval Juárez

Código 20061015

Lima - Perú 
Materia: Anulación de Laudo Arbitral

$\mathrm{N}^{\circ}$ de Expediente: 00156-2014-0-1817-SP-CO-01

Materia: Procedimiento Administrativo Sancionador - Pesquero

$\mathrm{N}^{\circ}$ de Expediente: 3238-2012-PRODUCE/DIGSECOVI 